\title{
The asymmetric and threshold impact of external debt on economic growth: new evidence from Egypt
}

\author{
Mesbah Fathy Sharaf \\ Department of Economics, University of Alberta Faculty of Arts, \\ Edmonton, Canada and \\ Department of Economics, Faculty of Commerce Damanhour University, \\ Damanhour, Egypt
}

\begin{abstract}
Purpose - Within a multivariate framework, this study examines the asymmetric and threshold impact of external debt on economic growth in Egypt during the period 1980-2019.

Design/methodology/approach - The paper uses a nonlinear autoregressive distributed lag (NARDL) bounds testing approach to cointegration and a vector error-correction model to estimate the short- and longrun parameters of equilibrium dynamics. A multiple structural breaks model is estimated to test nonlinearity in the relationship between external debt and economic growth.

Findings - Results of the NARDL model show a robust statistically significant negative long-run impact on economic growth stemming from both positive and negative external-debt-induced shocks. In terms of magnitude, on the one hand, the impact of external-debt-induced negative shocks exceeds that of the positive. In the short and long run, on the other hand, the growth impact of external debt in Egypt is symmetric. There is also support for the nonlinearity hypothesis in which a negative impact on growth of external debt obtains once the threshold level of external debt-to-GDP ratio equals or exceeds $96.7 \%$.

Practical implications - Identifying the threshold level after which external debt becomes harmful to economic growth would help inform policymakers in Egypt about maximum external debt levels that can be sustained without impairing economic growth.

Originality/value - The current study makes a substantial contribution to the extant literature on the debtgrowth tradeoffs. It breaks ground by being the first tract that examines, using a NARDL model, asymmetry and nonlinearity of debt-growth tradeoffs in Egypt.
\end{abstract}

Keywords External debt, NARDL, Bounds test, Economic growth, Egypt

Paper type Research paper

\section{Introduction}

The nature of the relationship between external debt and economic growth has received growing attention among academics and policymakers that reflects the potentially serious repercussions of unsustainable external debt burdens on the practical workability of macroeconomic policies.

(C) Mesbah Fathy Sharaf. Published in Journal of Business and Socio-economic Development. Published by Emerald Publishing Limited. This article is published under the Creative Commons Attribution (CC BY 4.0) licence. Anyone may reproduce, distribute, translate and create derivative works of this article (for both commercial and non-commercial purposes), subject to full attribution to the original publication and authors. The full terms of this licence may be seen at http://creativecommons.org/licences/by/4.0/ legalcode

The author would like to thank the Editor in Chief of this Journal Dr. Allam Hamdan and the anonymous referees for the invaluable comments and suggestions that substantially improved the manuscript throughout the review process. The author would also like to thank Dr. Richard Cummings for the professional language proofreading.

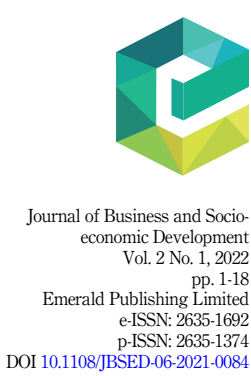

Received 25 June 2021

Revised 27 August 2021

28 September 2021

14 October 2021

Accepted 18 October 2021

debt-growth

nexus

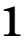
1 
JBSED 2,1

Perennially hamstrung by feeble hard currency earnings attributable to unfavorable terms of trade, Egypt has been relying for decades on external borrowing to finance its chronic current account deficits. Egypt's external debt has ballooned over the past decade to the extent that it holds the dubious distinction of its being the fastest-growing country in MENA in terms of external debt. External debt in excess of safe threshold levels has been perceived as a threat to economic growth and could result in a breakdown of its macroeconomic policies. There is a concern that the external debt level in Egypt has climbed to economically unsustainable levels forcing a siphoning off of financial resources to service the debt burden from physical and human capital accumulation and other productive uses.

The current study aims to examine the long-run causal impact, in a Granger sense, of external debt on economic growth in Egypt during the period 1980-2019. This study involves an examination of the extent to which: (1) the growth impact of external debt in Egypt is asymmetric; and (2) the external debt-growth relationship is nonlinear. This paper contributes to the extant literature on the debt-growth trade off by presenting new evidence from Egypt on the asymmetric and nonlinear growth effects of external debt using the nonlinear autoregressive distributed lag (NARDL) approach of Shin et al. (2014) and the multiple structural breaks model of Bai and Perron (2003).

The findings of previous related studies are mostly based on symmetric models that do not account for plausible asymmetric effects of external debt and implicitly assume linearity in the relationship between external debt and economic growth. To the best of the author's knowledge and to date, the current study is the first that examines the asymmetry and nonlinearity in debt-growth tradeoffs in Egypt. It has been shown that failure to control for nonlinearity in the relationship could lead to biased estimates and unreliable inference and forecasts (Shin et al., 2014). In addition, key macroeconomic variables such as GDP and debt usually exhibit nonlinear properties, for which the linear symmetric models cannot account.

The rest of the paper is organized as follows: Section 2 presents a brief review of the related literature. Section 3 provides a snapshot of the evolution of external debt in Egypt, and section 4 presents the data and methodology. Section 5 presents the empirical results, which are then discussed in section 6 . Section 7 concludes the paper.

\section{A review of the theoretical and empirical literature}

Theoretically, external debt could have a positive, negative or neutral impact on economic growth. Keynesians hypothesized a positive impact for reasonable public debt levels on economic growth under the assumption of perfect capital mobility. They argue that increasing government spending through borrowing in credibly productive activities, such as infrastructure, expands aggregate demand and boosts economic growth. Early proponents of classical economics, guided by laissez faire principles, advocated nongovernmental intervention in economic activities. This was reflected by their opposing view to government borrowing, except in emergencies such as wars or disasters. Spawned from the debt overhang theory of Krugman (1988), a hypothesis positing a negative relationship between public debt and economic growth has emerged with the idea that in serving, in effect, as a tax on future output, high debt levels reduce incentives for savings and investment, both domestic and foreign (Reinhart, 2012).

Several scholars have posited that the debt overhang effects on economic growth might operate through channels other than the discouragement of the volume of investment. For instance, high levels of external debt may discourage the government from implementing policy reforms such as fiscal adjustments and trade liberalization. Such inertia would negatively affect economic growth by creating a poorer macroeconomic policy environment. This would affect not only the volume but also the efficiency of investment. Uncertainty in debtor ability to repay could lead to a distortion of the allocation of investment by inducing 
investors to favor short-term over long-term capital projects - a tradeoff which would serve to reduce gains attributable to investment that otherwise would have been realized on economic growth (Pattillo et al., 2011).

The third point of view considers debt to have a neutral impact on economic growth. According to Barro-Ricardo's equivalence proposition, public debt has a neutral impact on economic growth. This proposition is based on the Ricardian equivalence. Increasing debtfinanced government spending will not stimulate economic growth because investors and consumers are aware that the debt will eventually be repaid through higher future taxation. Economic actors adapt their behaviors accordingly (Barro, 1989).

Empirically, a growing literature on the interrelationship between debt and growth has emerged with inconclusive findings. (For a recent systematic review of the literature on the public debt effect on economic growth, see Abd Rahman et al., 2019). While several studies attributed to external debt a positive effect on economic growth (see, e.g. Bakar and Hassan, 2008), other studies, on the contrary, found a negative impact (see, e.g. Kharusi and Ada, 2018). In a set of emerging countries (Armenia, Azerbaijan, Belarus, Bulgaria, Georgia, Kazakhstan, Kyrgyzstan, Moldova, Romania, Tajikistan and Ukraine), Shkolnyk et al. (2018) found a negative impact of external debt on economic growth, to a statistically significant extent at the $5 \%$ confidence level, only present with respect to Armenia, Azerbaijan, Belarus, Kazakhstan, Moldova and Ukraine.

To add to the contention, yet a third group of studies found no impact whatsoever (see, e.g. Ogunmuyiwa, 2011). For example, Abu Bakar and Hassan (2008) found that external debt positively affected economic growth in Malaysia during the period 1970-2005. Using an ARDL model, Kharusi and Ada (2018) found a statistically significant negative effect of external debt on economic growth in Oman during the period 1990-2015. Ogunmuyiwa (2011) found a weak and insignificant relationship between external debt and economic growth in Nigeria during 1970-2007 using cointegration and Granger causality analyses.

Very few studies have investigated how and to what extent external debt has affected economic growth in Egypt, whether directly or indirectly (see, e.g. Abouelfarag and Abed, 2019). Moreover, not one of these very few studies has examined the potential asymmetry and nonlinearity in the relationship between external and economic growth.

In their seminal work, Reinhart and Rogoff (2010) and Reinhart et al. (2012) hypothesized the existence of a nonlinear pattern in the relationship between external debt and economic growth. They argued that below a certain threshold level, a debt-to-GDP ratio of $90 \%$, external debt has a positive but often a statistically insignificant impact on economic growth, while after that threshold level, the growth impact of external debt turns to be negative. The findings of several empirical studies supported this threshold hypothesis. However, no consensus exists with respect to the value of that threshold level (see, e.g. Pattillo et al., 2004 for evidence in a panel of 61 developing countries). Checherita-Westphal and Rother (2012) found debt to have a nonlinear impact on growth in twelve Eurozone countries with a turning point - after which the government debt-to-GDP ratio harms long-term economic growth - at about $90-100 \%$ of the GDP. It is worth mentioning that one of the convergence criteria that is a prerequisite for joining the Eurozone is to have a government debt-to-GDP ratio of less than $60 \%$. Interestingly, Shkolnyk et al. (2018) estimated the external debt over GDP pivot point of Ukraine, a candidate for EU membership, at $63 \%$.

Cross-country studies, with few country-specific studies, make up the bulk of the empirical literature that tests the nonlinear/threshold relationship between debt and economic growth. In a recent study using an asymmetric panel ARDL method applied to a panel of 14 Asian countries, Asteriou et al. (2021) found evidence for an asymmetric growth impact of public debt in the short run.

A few studies have also investigated the asymmetric impact of external debt on economic growth on a country-specific level but with varied findings. For instance, using quarterly data 
JBSED

2,1

4

and asymmetric causality testing, Toktaş et al. (2019) found an asymmetric relationship between external debt and economic growth in Turkey over the period 2003 to 2107. Likewise, Pegkas (2018) examined the threshold effects of general government debt on economic growth in Greece over the period 1970-2016. The author found that government debt depresses economic growth - a negative impact escalating in severity as debt levels rise.

It is apparent from this review that the findings of the previous studies are inconclusive regarding the impact of external debt on economic growth. Such disparities could be attributable to alternative methodologies used and variations in periods under investigation. In addition, that countries differ in terms of institutional competency, economic structure, applied macroeconomic policies and degree of severity of economic problems may well affect the impact of external debt on economic growth on a country-specific level. Moreover, the impact of external debt on economic growth could reflect industrial organization or the technological level of a given economy (De Vita et al., 2018).

\section{An overview of the evolution of external debt in Egypt}

External debt indicators in Egypt provide a window to observe changes, often stark, in economic policies, macroeconomic conditions, political regimes and effects of shocks, both internal and external.

In 1970, external debt in Egypt amounted to about $\$ 1.8$ billion. By the mid-1970s, however, external debt more than tripled to $\$ 6.4$ billion, mainly due to the 1973 October War and the implementation in 1975 of an open-door policy, which created a substantial current account deficit. As depicted in Figure 1, external debt by 1982 had increased substantially reaching $\$ 22$ billion - almost equal to the country's GDP. In 1988, external debt peaked reaching 46.1 billion dollars attaining the highest external debt-to-GDP ratio 131.9\% during the whole study period. The accelerated growth of external debt during the 1980s has been attributed to escalating current account deficits. A sharp decline in Egypt's foreign exchange revenues arose from a series of adverse internal and external shocks. These include the slowdown in the world growth rates during that period and the decline in international oil prices, which reduced workers' remittances to Egypt and the Suez Canal revenues. In

Figure 1.

External debt stock and external debt-toGDP ratio in Egypt over the period 1980-2019

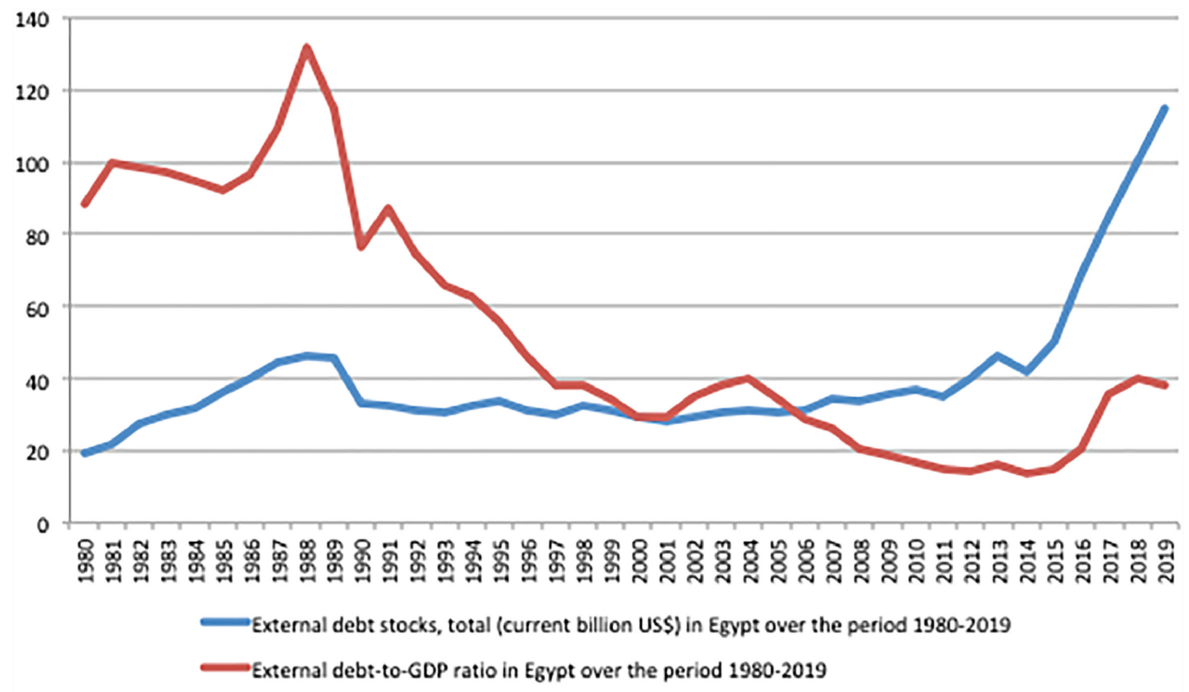

Source(s): Author's calculation based on data from the World development indicators 
addition, the tourism sector plunged in the aftermath of several terrorist attacks during that period. All these factors contributed to a sharp decline in Egypt's foreign reserves shrinking to 2.5 billion dollars in 1989. Consequently, the Egyptian pound, which lost more than half of its value against the U.S. dollar, went into free-fall (World Development Indicators, 2021).

In the 1990s, total external debt and the external debt-to-GDP ratio, as depicted in Figure 1, followed a continuous downward trend, reaching $\$ 29.2$ billion and $29.3 \%$, respectively. This improvement in the external debt indicators during the 1990s' is partly attributable to the writing-off of a substantial amount of Egypt's external debt by its creditors as a reward to Egypt's participation in the international alliance to free Kuwait in 1990. In addition, in consultation with the IMF, Egypt's implementation in 1991 of the Economic Reform and Structural Adjustment Program (ERSAP) contributed to the improvement in the external debt indicators.

At the beginning of the new millennium, external debt started to rise gradually, reaching $\$ 36.8$ billion in 2010, possibly due to the slowdown in global growth because of the 2008 global financial crisis. In 2011, more significantly, the external debt jumped from $\$ 35.2$ billion to $\$ 46.5$ billion in an environment characterized by political turmoil during the Arab Spring. There is empirical evidence that several economic growth determinants in the MENA region are sensitive to political instability (Awad et al., 2021). International reserves and foreign exchange sources dried up in the ensuing chaos. By 2014, however, external debt declined to 41.7 billion dollars, and, measured as a percentage of GDP, plummeted to its lowest level during the whole study period $(13.7 \%)$ largely attributable to increased grants and gifts to the Egyptian government from some Arab countries (Central Bank of Egypt, 2015). After 2014, however, a new political regime witnessed the upward creeping of external debt in line with a combination of a sharp decline in remittance, Suez Canal, and tourism revenues with a fall in exports and FDI. In response, the Egyptian government sought external borrowing from international organizations such as the IMF and the World Bank to compensate for the drop in foreign exchange receipts. Subsequently, the external debt continued to balloon reaching an unprecedented record of about 125.3 billion dollars in 2020 .

\section{Data and methodology}

This paper uses annual data on GDP $(Y)$, gross fixed capital formation $(K)$ as a measure of physical capital, the employment rate $(E)$ and external debt (debt). The data are retrieved from the World Development Indicators. The analysis covers the period from 1980 to 2019. All variables are expressed in natural logarithmic form.

Pre-testing all-time series for unit root is undertaken to ensure a non-spurious estimation and efficient and time-invariant estimates. It is also essential to test the stationarity of the time series to be sure that none of the variables is integrated of an order greater than one I(1); otherwise, the bounds test for cointegration will not be valid. Two traditional unit root tests, the augmented Dickey-Fuller (ADF) (Dickey and Fuller, 1979) test and the KwiatkowskiPhillips-Schmidt-Shin (KPSS) test, are used. Two versions of the ADF and KPSS tests are used; one version allows for an intercept, and a second allows for an intercept and a deterministic trend. To account for any potential structural breaks in the time series when testing for the unit root, the analysis uses Zivot and Andrews (2002) unit root test, which tests stationarity with one endogenously determined structural break.

After checking the order of integration of the variables, the existence of a long-run relationship, cointegration, between the variables is tested using the bounds test for cointegration within a NARDL unrestricted error-correction model. Once the cointegration is verified between the variables, the analysis proceeds by estimating the long-run and shortrun asymmetric impact of external debt on economic growth. The asymmetric impact of external debt on economic growth is accounted for by including the positive changes, debt ${ }_{t}^{+}$,

\section{External debt-growth nexus}


JBSED

2,1

6

and negative changes, $\mathrm{debt}_{t}^{-}$, in the external debt as explanatory variables in the aggregate production function. Where the debt $t_{t}^{+}$and $d e b t_{t}^{-}$are the partial sums of the positive and negative changes in the external debt ${ }_{i}$, respectively:

$$
\begin{aligned}
\operatorname{debt}_{t}^{+} & =\sum_{i=1}^{t} \Delta \text { debt }_{t}^{+}=\sum_{i=1}^{t} \max \left(\text { debt }_{i}, 0\right) \\
\operatorname{debt}_{t}^{-} & =\sum_{i=1}^{t} \Delta \text { debt }_{t}^{-}=\sum_{i=1}^{t} \min \left(\text { debt }_{i}, 0\right)
\end{aligned}
$$

To test the existence of an asymmetric long-run equilibrium relationship between economic growth and external debt, i.e. cointegration, the current paper uses a NARDL approach proposed by Shin et al. (2014), which can be presented as in Equation (3). Unlike the linear ARDL model, the merit of the NARDL model is that it allows for the measuring of the asymmetric impact of the external debt on GDP in both the short-run and the long-run.

$$
\begin{aligned}
\Delta Y_{t}= & \gamma_{1}+\sum_{i=1}^{p} \theta_{1 i} \Delta Y_{t-i}+\sum_{i=1}^{q} \theta_{2 i} \Delta E_{t-i}+\sum_{i=1}^{r} \theta_{3 i} \Delta K_{t-i}+\sum_{i=1}^{s} \theta_{4 i} \Delta \mathrm{debt}_{t-i}^{+} \\
& +\sum_{t=1}^{t} \theta_{5 i} \Delta \mathrm{debt}_{t-i}^{-}+\tau_{1} Y_{t-1}+\tau_{2} E_{t-1}+\tau_{3} K_{t-1}+\tau_{4} \mathrm{debt}_{t-1}^{+}+\tau_{5} \mathrm{debt}_{t-1}^{-}+\varepsilon_{t}
\end{aligned}
$$

In which $\Delta$ is a first difference operator, $Y_{t}$ refers to GDP, $K_{t}$ is the gross fixed capital formation, $E_{t}$ is the employment rate, $\mathrm{debt}_{t}^{+}$and $\mathrm{debt}_{t}^{-}$are the positive and negative changes in external debt. $p, q, r, s, t$ represent the optimal lag order determined based on the Akaike or the Schwarz information criterion.

Testing the existence of a long-run relationship between external debt and GDP uses an $F$-test for the joint significance of the coefficients of the lagged level variables $\left(H_{0}: \tau_{1}=\tau_{2}=\tau_{3}=\tau_{4}=\tau_{5}=0\right)$. Pesaran et al. (2001) provided lower and upper bound critical values for the $F$-statistics as it does not follow the standard distributions. Cointegration between the variables is established if the $F$-statistic exceeds the upper bound critical values.

The NARDL bounds testing approach has several advantages over other cointegration tests. It is relatively more robust in small samples, is not sensitive to orders of integration of the variables of interest and yields unbiased estimates and valid statistics, despite having endogenous regressors. It also controls for the existence of structural breaks in the time series.

The error-correction representation of the NARDL model presented in Equation (3) is exhibited in Equation (4).

$$
\begin{aligned}
\Delta Y_{t}= & \alpha+\sum_{i=1}^{p} \beta_{1 i} \Delta Y_{t-i}+\sum_{i=1}^{q} \beta_{2 i} \Delta E_{t-i}+\sum_{i=1}^{r} \beta_{3 i} \Delta K_{t-i}+\sum_{i=1}^{s} \beta_{4 i} \Delta \operatorname{debt}_{t-i}^{+} \\
& +\sum_{i=1}^{t} \beta_{5 i} \Delta \operatorname{debt}_{t-i}^{-}+\varnothing \mathrm{ECT}_{t-1}+\varepsilon_{t}
\end{aligned}
$$

The coefficient of the error-correction term $\varnothing$, reflects the speed of adjustment of $Y, E, K$ and debt to their long-run equilibrium, following any shock. This coefficient measures the proportion of the last period disequilibrium that is corrected for in the current period. Dynamic stability requires this coefficient to be negative and less than unity. 
The short-run and long-run asymmetric impact of external debt on economic growth is also assessed by deriving the cumulative dynamic multiplier, which measures the percentage point change in economic growth due to a one percent change in debt $_{t-1}^{+}$and debt $t_{t-1}^{-}$.

To test the existence of a nonlinear relationship between external debt and economic growth, a multiple structural breaks model of Bai and Perron (2003) is estimated. A multiple structural breaks linear model of the impact of external debt on economic growth with $T$ periods and $m$ structural breaks, which generate $m+1$ regimes, can be presented as in Equation 5.

$$
Y_{t}=\gamma_{i} \mathrm{debt}_{t}+\varphi_{i} X_{t}+u_{t}, i=1, \ldots, m+1, t=T_{i-1}+1, \ldots, T_{i}
$$

In which $Y_{t}$ is the GDP, $X_{t}$ is a vector of the other control variables discussed earlier, debt $_{t}$ is the external debt. $\gamma_{i}$ and $\varphi_{i}$ are the corresponding vectors of regime-dependant coefficients for $i=1, \ldots, m+1$, and $u_{t}$ is the error term.

As suggested by Bai and Perron (2003), the number of statistically significant breaks, $m$, is determined endogenously by a sequential algorithm where the first breakpoint is identified, and the sample is stratified into two sub-samples, and a test is conducted to test the null hypothesis of one regime against the alternative two regimes. Then the null hypothesis of a two-regime model is tested against the alternative hypothesis of a three-regime model. The same procedure is implemented for each sub-sample until the $m$ regimes are reached, and the null hypothesis is not rejected for this $m$ at the $5 \%$ significance level.

\section{Empirical results}

\subsection{Unit root tests}

Results of the ADF and KPSS unit root tests of the variables in levels and in first difference are reported in Table 1. According to both tests, GDP and $E$ are stationary at level in the trend and intercept version of the tests, while the $K$ time series is stationary according to the KPPS test in the version that has an intercept and a trend. The result also shows that the external debt series is non-stationary at level across all specifications of the tests. More importantly, both tests reveal that all the variables become stationary at their first difference, which means that all the variables are integrated of order one I(1).

Results of the Andrew-Zivot unit root test for the variables at level, presented in Table 2, show that GDP and $K$ are stationary at levels with one structural break across both versions of the test, while $E$ and the external debt are stationary at level in the version that has a

\begin{tabular}{|c|c|c|c|c|c|c|c|c|}
\hline & \multicolumn{2}{|c|}{ GDP } & \multicolumn{2}{|c|}{ Capital } & \multicolumn{2}{|c|}{ Employment } & \multicolumn{2}{|c|}{ Debt } \\
\hline & $\mathrm{ADF}$ & KPSS & $\mathrm{ADF}$ & KPSS & $\mathrm{ADF}$ & KPSS & $\mathrm{ADF}$ & KPSS \\
\hline \multicolumn{9}{|c|}{ Unit root tests of variables in levels } \\
\hline Intercept & -0.82 & $0.75^{* * *}$ & -0.62 & $0.73^{* * *}$ & -2.47 & $0.61^{* *}$ & 0.97 & $0.47^{* *}$ \\
\hline $\begin{array}{l}\text { Trend and } \\
\text { intercept }\end{array}$ & $-3.87 * *$ & 0.07 & -2.91 & 0.07 & $-3.51^{*}$ & 0.07 & 0.31 & $0.16^{* *}$ \\
\hline None & 2.32 & & 1.48 & & -0.54 & & 1.43 & \\
\hline \multicolumn{9}{|c|}{ Unit root tests of variables in first difference } \\
\hline Intercept & $-4.32 * * * *$ & 0.057 & $-4.31^{* * * *}$ & 0.059 & $-5.60 * * *$ & 0.13 & $-3.89 * * *$ & 0.24 \\
\hline $\begin{array}{l}\text { Trend and } \\
\text { intercept }\end{array}$ & $-4.27 * * *$ & 0.058 & $-4.18^{* *}$ & 0.058 & $-5.64 * * *$ & 0.08 & $-4.07^{* * *}$ & 0.17 \\
\hline None & $-3.42^{* * * *}$ & & $-3.97 * * *$ & & $-5.63^{* * * *}$ & & $-3.57 * * *$ & \\
\hline
\end{tabular}

Note(s): *, **, *** imply rejection of the null hypothesis at the $10 \%, 5 \%$ and $1 \%$ significance level, respectively. For the ADF (KPSS) test, the null hypothesis is that the series is non stationary (stationary)

\section{External debt-growth nexus}


JBSED 2,1

8

structural break in the trend. Similar to the finding of the ADF and KPSS tests, though for brevity, the results are not reported; all the time series, at the first difference, become stationary with one structural break.

\subsection{Cointegration bounds test and the linear and nonlinear ARDL estimates}

Results of the cointegration bounds test reveal both a linear and a nonlinear long-term relationship between GDP, $K, E$ and external debt. For the linear ARDL $(1,3,3,2)$ model, the value of the $F$-statistic of the bounds test is 6.61 , which is greater than the upper bound of the critical value (5.64) at the 5\% significance level. Similarly, the $F$-statistic value of the NARDL $(1,3,3,1,2)$ model equals 5.34 , which is also greater than the upper bound of the critical value (5.22) at the $5 \%$ significance level.

Table 3 presents the short-run and long-run coefficients of the estimated ARDL and NARDL models. The estimated long-run coefficients of both the linear and nonlinear ARDL models show that employment has no statistically significant long-run effect on economic growth, while fixed capital formation has a statistically significant positive impact. As for the effect of external debt, the linear ARDL model shows a statistically significant long-run negative impact for external debt on economic growth. An increase in external debt by $1 \%$ reduces economic growth by $0.65 \%$. Results of the NARDL model show a statistically significant negative long-run impact for both the positive and negative shocks to external debt on economic growth, though the magnitude of the impact of the negative changes in external debt is greater than that of the impact of the positive changes. The coefficient on the error-correction term is negative and statistically significant, indicating the convergence in the variables' long-run dynamics. In the estimated ARDL $(1,3,3,2)$ and NARDL $(1,3,3,1,2)$ models, 43 and $41 \%$ of last period's disequilibrium is corrected in the current period, respectively. This means that after a shock, it takes less than 2.5 years for GDP, $K, E$ and external debt to restore their long-run equilibrium relationship.

A set of diagnostic tests has been conducted to check the competency of the estimated models. These include the Lagrange multiplier (LM) test of residual serial correlation, Ramsey's RESET test for specification error, Jarque-Bera's normality test based on the skewness and kurtosis of residuals and the Breusch-Pagan-Godfrey's heteroscedasticity test based on the regression of squared residuals on squared fitted values. Several parameters stability diagnostics have also been conducted, including the cumulative sum of recursive residuals (CUSUM) test and the cumulative sum of squares of recursive residuals (CUSUM of squares) test.

As evident in Figure 2, the estimated coefficients of the ARDL $(1,3,3,2)$ and NARDL $(1,3,3,1,2)$ models are stable at the $5 \%$ significance level. Also, the results of the diagnostic tests that are presented in Table 3 show that the estimated linear and nonlinear ARDL models are free from heteroskedasticity, serial correlation, non-normality of the residuals and specification error at the 5\% significance level.

Table 2.

Results of AndrewZivot unit root test of the variables in level

\begin{tabular}{|c|c|c|c|c|c|c|c|c|}
\hline & \multicolumn{8}{|c|}{ Unit root tests of variables in levels } \\
\hline & \multicolumn{2}{|c|}{ GDP } & \multicolumn{2}{|c|}{ Capital } & \multicolumn{2}{|c|}{ Employment } & \multicolumn{2}{|c|}{ Debt } \\
\hline & $T$-statistic & $\begin{array}{l}\text { Time } \\
\text { break }\end{array}$ & $T$-statistic & $\begin{array}{l}\text { Time } \\
\text { break }\end{array}$ & $T$-statistic & $\begin{array}{l}\text { Time } \\
\text { break }\end{array}$ & $T$-statistic & $\begin{array}{l}\text { Time } \\
\text { break }\end{array}$ \\
\hline Inte & $-4.72 * *$ & 2012 & $-4.47 * *$ & 2007 & -3.76 & 1996 & -1.59 & 2013 \\
\hline Trend & $-4.49 *$ & 2003 & $-4.39 * *$ & 2004 & $-4.07 * *$ & 1996 & $-3.73^{* * *}$ & 2012 \\
\hline
\end{tabular}

Note(s): *, **, *** imply rejection of the null hypothesis of a unit root with a structural break at the $10 \%, 5 \%$ and $1 \%$ significance level, respectively 
Panel (A)

$\operatorname{ARDL}(1,3,3,2)$

NARDL $(1,3,3,1,2)$

Short run coefficients

\begin{tabular}{|c|c|c|c|c|}
\hline Trend & $0.003^{* * * *}$ & 0.00 & -0.0003 & 0.00 \\
\hline$\Delta(\ln E)$ & 0.403 & 0.61 & 0.24 & 0.57 \\
\hline$\Delta(\ln E(-1))$ & -0.412 & 0.62 & -0.70 & 0.58 \\
\hline$\Delta(\ln E(-2))$ & $1.59 * *$ & 0.64 & $1.17 *$ & 0.62 \\
\hline$\Delta(\ln K)$ & $0.77^{* * * *}$ & 0.07 & $0.75^{* * *}$ & 0.06 \\
\hline$\Delta(\ln K(-1))$ & $-0.16^{*}$ & 0.08 & $-0.14^{*}$ & 0.08 \\
\hline$\Delta(\ln K(-2))$ & $-0.40 * * *$ & 0.09 & $-0.33^{* * *}$ & 0.07 \\
\hline$\Delta$ (lndebt) & -0.13 & 0.09 & & \\
\hline$\Delta(\operatorname{lndebt}(-1))$ & $0.28^{* *}$ & 0.10 & & \\
\hline$\Delta\left(\right.$ lndebt $\left.^{+}\right)$ & & & 0.07 & 0.14 \\
\hline$\Delta\left(\right.$ lndebt $\left.^{-}\right)$ & & & $-0.30 *$ & 0.16 \\
\hline$\Delta\left(\operatorname{lndebt}^{-}(-1)\right)$ & & & $0.46^{* * *}$ & 0.15 \\
\hline $\mathrm{ECT}_{t-1}$ & $-0.43^{* * *}$ & 0.08 & $-0.41 * * *$ & 0.07 \\
\hline
\end{tabular}

Panel B

Long run coefficients

\begin{tabular}{|c|c|c|c|c|}
\hline $\begin{array}{l}\ln E \\
\ln K \\
\text { ln debt } \\
\text { ln debt } \\
\text { ln debt }\end{array}$ & $\begin{array}{rr}-0.78 & 2.19 \\
1.42^{* * * *} & 0.23 \\
-0.65^{* * *} & 0.19\end{array}$ & $\begin{array}{l}-0.005 \\
1.40^{* * *} \\
-0.50 * * \\
-0.81^{*}\end{array}$ & $\begin{array}{l}2.34 \\
0.26 \\
\\
0.21 \\
0.41\end{array}$ & \\
\hline Diagnostic tests & ARDL $(1,3,3,2)$ & \multicolumn{2}{|c|}{ NARDL $(1,3,3,1,2)$} & \\
\hline Serial correlation & $\begin{array}{l}\chi^{2}(2)=0.04 \\
p \text { value }(0.97)\end{array}$ & & & \\
\hline Heteroskedasticity & $\begin{array}{c}\chi^{2}(13)=21.98 \\
p \text { value }(0.07)\end{array}$ & & 1.64 & $\begin{array}{r}\text { Estimated short run } \\
\text { and long run }\end{array}$ \\
\hline Functional form & $\begin{array}{l}F(1,22)=2.43 \\
p \text { value }(0.13)\end{array}$ & & 130 & $\begin{array}{l}\text { parameters of the } \\
\text { ARDL }(1,3,3,2) \text { and }\end{array}$ \\
\hline Normality & $\begin{array}{c}\text { Jarque-Bera }=1.64 \\
p \text { value }(0.43)\end{array}$ & & $\begin{array}{l}=0.73 \\
69)\end{array}$ & $\begin{array}{r}\text { NARDL }(1,3,3,1,2) \\
\text { models }\end{array}$ \\
\hline
\end{tabular}

Results of the NARDL asymmetric effects test show that the null hypothesis of symmetry in effect cannot be rejected both in the long run (long run asymmetry test: $\chi^{2}(1)=0.36, p$ value $=0.54$ ) and in the short run (Short run asymmetry test: $\chi^{2}(1)=0.81$, $p$ value $=0.81$ ), as the $p$ values of the chi-square statistics are greater than the $5 \%$ significance level.

Figure 3 depicts the dynamic asymmetric multiplier of the NARDL $(1,3,3,1,2)$ model and reveals an apparent symmetry in the long-run adjustment patterns following a shock to the external debt. This finding is in line with the result of the asymmetric effects test presented earlier. The solid black line of the dynamic multiplier plots shows that a $1 \%$ increase in external debt increases GDP, negligibly, by less than $0.07 \%$ in the short run, and then, in the long run, it reduces GDP by about $0.5 \%$. Similarly, the black-dashed line of the dynamic multiplier plots reveals that a $1 \%$ decline in external debt increases GDP by less than $0.4 \%$ in the short run, and this converges to about $0.8 \%$ in the long run. Remarkably, the net effect of external debt (thick red-dashed line) is positive both in the short run and in the long run, increasing and then decreasing in the short run and finally increasing in the long run, converging to around $0.3 \%$. 
JBSED

2,1

10

Figure 2.

ARDL $(1,3,3,2)$ and

NARDL $(1,3,3,1,2)$

CUSUM and

CUSUMSQ

stability plots

Figure 3.

NARDL $(1,3,3,1,2)$

dynamic asymmetric multiplier

$\operatorname{ARDL}(1,3,3,2)$

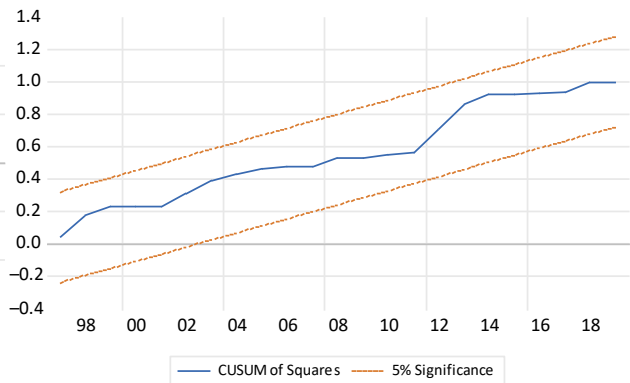

(a)

NARDL $(1,3,3,1,2)$
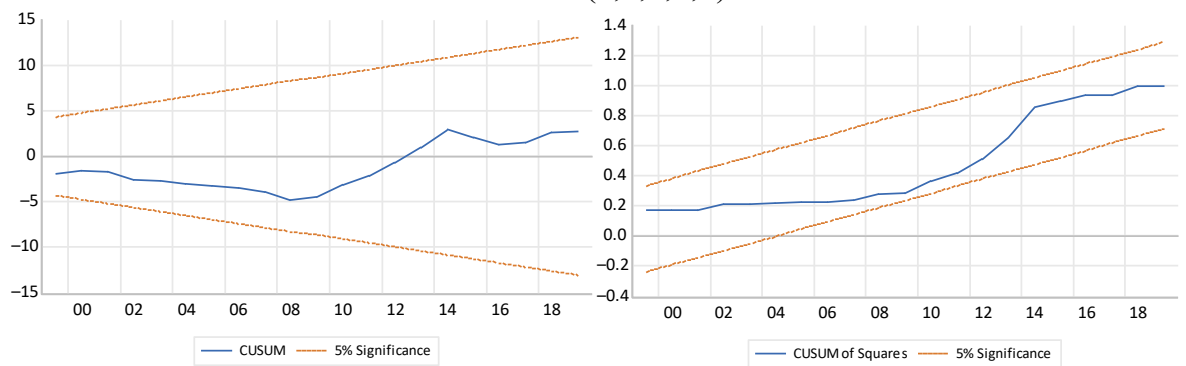

(b)

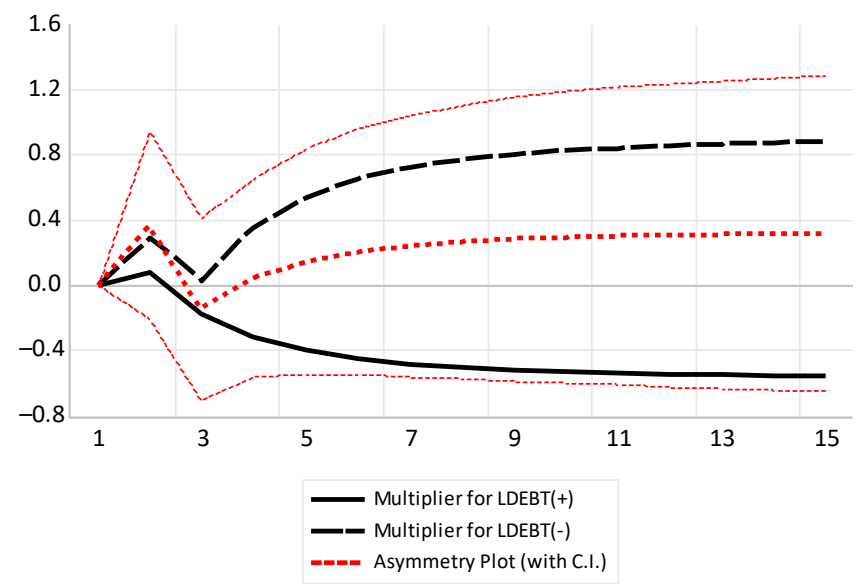

5.3 Multiple structural breaks tests and estimation results

Table 4 presents the results of the multiple structural breaks model of Bai and Perron (2003). The results show that the null hypothesis of the linear model is rejected against the alternative of a two-regime model at the 5\% significance level and the break date is 1986 with a threshold value of the external debt-to-GDP ratio of $96.7 \%$. The null of a two-regime (one 
break) model is then tested against the alternative of a three-regime (two breaks) model. In this case, the null hypothesis is also rejected at the $5 \%$ significance level, and the break date is 1996 with a threshold value of the external debt-to-GDP ratio of $46.59 \%$. Next, the null of a three-regime (two breaks) model is tested against the alternative of a four-regime (three breaks) model, and the null hypothesis is also rejected at the $5 \%$ significance level, and the break date is 2008 with a threshold value of the external debt-to-GDP ratio of $20.82 \%$. Finally, the null of a four-regime (three breaks) model is tested against the alternative of a five-regime (four breaks) model, and in this case, the null hypothesis is not rejected at the $5 \%$ significance level.

Table 5 presents the results of the multiple structural breaks estimation over the period 1980-2019.

The break model for the sub-period 1980-1985 shows that the external debt has a statistically insignificant positive impact on economic growth. For the sub-period 1986-1995, external debt has a statistically significant negative impact on economic growth in which a $10 \%$ increase in external debt is associated with a $7.7 \%$ decline in economic growth. The negative impact of external debt on economic growth during the 1986-1995 period reflects the high external debt-to-GDP ratio, which reached $97 \%, 109 \%, 132 \%$, respectively, in 1986, 1987 and 1988. The results also show that physical capital formation has a statistically significant positive impact on economic growth in Egypt over the period 1986 to 2019. For the sub-period 19962007, the external debt had no statistically significant impact on economic growth. During the sub-period, 2008-2019, external debts had a statistically significant, minor, positive impact on economic growth where a $10 \%$ increase in external debt is associated with a $1 \%$ increase in economic growth. This positive impact over the 2008-2019 period reflects the low external debtto-GDP ratio, which bottomed out at $15 \%$ in 2011 only to increase modestly to $20 \%$ in 2016 .

\subsection{Robustness checks}

Several previous studies (see, e.g. Pattillo et al., 2011) found that the growth impact of external debt could be sensitive to model specification. The current study conducted a sensitivity

\begin{tabular}{lcccc}
\hline Break test & $F$-statistic & Scaled $F$-statistic & Critical value & Estimated break date \\
\hline 0 vs $1^{*}$ & 53.77365 & 107.5473 & 11.47 & 1986 \\
1 vs $2^{*}$ & 33.94102 & 67.88203 & 12.95 & 1996 \\
2 vs ${ }^{*}$ & $9.503,037$ & 19.00607 & 14.03 & 2008 \\
3 vs 4 & 7.003890 & 14.00778 & 14.85 &
\end{tabular}

Note(s): * denotes significant at the 0.05 level. The critical values are Bai-Perron (Econometric Journal, 2003) critical values. A trimming of 0.15 is used

\section{External debt-growth nexus}

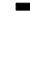


JBSED 2,1

analysis to ensure robustness by changing the model specification to check robustness of the debt-growth nexus with the inclusion of other growth determinants (such as human capital). In particular, the analysis is repeated by regressing output per worker on capital per worker, external debt and secondary school enrollments as a proxy for human capital. (Results of this robustness check beyond the brief discussion that follows are presented in an Appendix.) The results were, in general, qualitatively similar to the results presented in the previous sections. In particular, results of the bounds test show that output per worker, capital per worker, external debt and secondary school enrollments are cointegrated. The estimated ARDL models reveal a statistically significant negative impact of external debt on economic growth. The results of the NARDL asymmetric effects test presented in Table A3 in Appendix show that the null hypothesis of symmetry in effect cannot be rejected in the long run but is rejected in the short run.

The diagnostic tests presented in Table A2 in Appendix show that the estimated ARDL and NARDL models are free from any econometric problems and have stable coefficients at the $5 \%$ significance level.

Table A5, displayed in Appendix, presents the multiple structural breaks estimation results over the period 1980-2019. The break model for the sub-period 1980-1992 shows that the external debt has a statistically significant positive impact on economic growth. For the sub-period 1993-2003, external debt has a statistically significant negative impact on economic growth in which a $10 \%$ increase in external debt is associated with a $2.1 \%$ decline in economic growth. For the sub-period 2004-2009, the external debt had no statistically significant impact on economic growth. During the sub-period 2010-2019, external debts had a statistically significant, minor, positive impact on economic growth, reflecting the low external debt-to-GDP ratio.

\section{Discussion and policy implications}

Foreign debt transcends domestic debt as a threat to economic growth potential inasmuch as the former involves a transfer to foreign creditors of wealth with repayment contingent on extant foreign currency reserves, with which the indebted country may not be sufficiently endowed. Growing at an accelerated rate over the past decade, Egypt's external debt has reached an unprecedented level of 125.3 billion dollars in 2020. Soaring external debt has triggered concerns about whether the debt burden has already surpassed the tipping point beyond which economic growth is degraded. This study uses annual time series data from Egypt over 1980-2019 to check if such a tipping point in external debt exists in Egypt. Identifying the value of this tipping point would help inform policymakers in Egypt about safe external debt levels.

The results show a statistically significant symmetric negative long-run impact for both the positive and negative shocks to external debt on economic growth with the caveat that the magnitude of the impact of negative shocks in external debt exceeds that of the impact of positive shocks. The negative impact of external debt on economic growth that was found above a debt-GDP ratio threshold level of $96.7 \%$ could be explained by several factors documented in the literature. Such factors include channeling debt funds in non-productive activities (Shkolnyk and Koilo, 2018), ineffective debt management and inefficient handling of external debt flow and crowding out of the private investment (De Vita et al., 2018). Government debt dampens national savings available for future generations, potentially leading to an increase in interest rates, which negatively affects investment, both quantitatively and qualitatively, and concomitantly, economic growth. In an earlier study of a panel of 93 developing countries, Pattillo et al. (2011) found robust evidence that the effect of external debt on economic growth is determined more by the quality of investment (productivity) than by its magnitude. In addition, the prospects of future higher taxes needed 
to pay off the debt would worsen the investment climate in creating uncertainties that could lead to a distortion of financial resource allocation by pushing investors to substitute short term investment projects for long term ones - a substitution that would engender a smaller positive effect on economic growth (Pattillo et al., 2011).

The paper also found support for the nonlinearity hypothesis in which the growth impact of external debt becomes negative after a threshold level of external debt-to-GDP ratio of $96.7 \%$. This nonlinear pattern is in line with the findings of Reinhart and Rogoff (2010) and Reinhart et al. (2012). The results are also consistent with the findings of Pattillo et al. (2011), who found a nonlinear, hump-shaped relationship between external debt and economic growth in a panel of 93 developing countries which, at a debt-to-GDP ratio between 35 and $40 \%$, witnessed external debt switching from a positive to a negative influence on GDP growth.

The nonlinear impact of debt on economic growth has been explained by the nonlinear response of interest rates when a country reaches a "debt intolerance" level. High debt levels spike interest rates, pushing governments to adopt tight fiscal measures such as tax hikes or spending cuts that would dampen economic growth.

A key policy implication beyond the geographical confines of the current study (Egypt) is that proper management of debt within safe limits that channels any new external debt into more productive uses that have high added value to the economy would enhance economic growth. Several studies have shown positive effects on growth, stemming from high foreign debt burdens, where the borrowed funds are allocated to incremental investment in human capital. Human capital development would help boost labor productivity, raise profit opportunities of firms, which would increase incomes and render exports more competitiveall of which will reduce the reliance on foreign borrowing and facilitate the paying down of foreign debt (Otani and Villanueva, 1989). Freeing itself from exclusive reliance on external borrowing to finance development needs, the government of Egypt should base its economic growth strategies on attracting foreign direct investment, expanding exports, improving its competitiveness and productivity through technological innovation and enhancing the efficacy of its institutions. Implementing growth-enhancing structural reforms that do not rely exclusively on borrowing would also be a viable option.

\section{Conclusion}

This paper investigates the impact of external debt on GDP growth in Egypt and tests whether this relation is asymmetric and nonlinear over the period 1980-2019. In particular, this study aimed to estimate empirically the threshold level above which external debt would be harmful to economic growth. To achieve these objectives, the paper incorporates a set of time series methods, including symmetric and asymmetric ARDL framework and multiple structural breaks model of output and its determinants. The paper found robust evidence that the growth impact of external debt is symmetric in both the short and long runs and supports the nonlinearity hypothesis in which external debt becomes harmful to economic growth after a threshold level of external debt-to-GDP ratio of $96.7 \%$.

\section{Study limitations and further research}

The current study has focused on the asymmetric growth impact of external debt. Further research would be needed to assess the growth impact of rapidly rising domestic debt to fully understand how public debt affects economic growth in Egypt. One limitation of the current study is that it examined the impact of the aggregate external debt without reference to its composition. Additional insights could be garnered from an examination, subject to data availability, of how changes in the composition of the external debt would affect economic 
JBSED 2,1

growth. Another limitation stems from Granger causality failure to address any extant endogeneity problem.

\section{References}

Abd Rahman, N.H., Ismail, S. and Ridzuan, A.R. (2019), "How does public debt affect economic growth? A systematic review", Cogent Business and Management, Vol. 6 No. 1, p. 1701339.

Abouelfarag, H.A. and Abed, M.S. (2019), "The impact of foreign capital inflows on economic growth and employment in Egypt", Journal of Economic and Administrative Sciences, Vol. 36 No. 3, pp. 258-276.

Asteriou, D., Pilbeam, K. and Pratiwi, C.E. (2021), "Public debt and economic growth: panel data evidence for Asian countries”, Journal of Economics and Finance, Vol. 45 No. 2, pp. 270-287.

Awad, I.M., Al-Jerashi, G.K. and Alabaddi, Z.A. (2021), "Determinants of private domestic investment in Palestine: time series analysis", Journal of Business and Socioeconomic Development, Vol. 1 No. 1, pp. 71-86.

Bai, J. and Perron, P. (2003), "Computation and analysis of multiple structural change models”, Journal of Applied Econometrics, Vol. 18 No. 1, pp. 1-22.

Bakar, A. and Hassan, S. (2008), "Empirical evaluation on external debt of Malaysia", International Business and Economics Research Journal, Vol. 7 No. 2, pp. 95-108.

Barro, R.J. (1989), "The Ricardian approach to budget deficits", Journal of Economic Perspectives, Vol. 3 No. 2, pp. 37-54.

Central Bank of Egypt (2015), Annual Report 2014/2015, Central Bank of Egypt, Cairo, available at: https://cbe.org.eg/en/EconomicResearch/Publications/AnnualReportDL/Annual\%20Report 2014-2015.pdf.

Checherita-Westphal, C. and Rother, P. (2012), "The impact of high government debt on economic growth and its channels: an empirical investigation for the euro area", European Economic Review, Vol. 56 No. 7, pp. 1392-1405.

De Vita, G., Trachanas, E. and Luo, Y. (2018), "Revisiting the bi-directional causality between debt and growth: evidence from linear and nonlinear tests", Journal of International Money and Finance, Vol. 83, pp. 55-74.

Dickey, D.A. and Fuller, W.A. (1979), "Distribution of the estimators for autoregressive time series with a unit root", Journal of the American Statistical Association, Vol. 74 No. 366a, pp. 427-431.

Kharusi, S.A. and Ada, M.S. (2018), "External debt and economic growth: the case of emerging economy", Journal of Economic Integration, Vol. 33 No. 1, pp. 1141-1157.

Krugman, P. (1988), "Financing vs. forgiving a debt overhang", Journal of Development Economics, Vol. 29 No. 3, pp. 253-268.

Ogunmuyiwa, M.S. (2011), "Does external debt promote economic growth in Nigeria", Current Research Journal of Economic Theory, Vol. 3 No. 1, pp. 29-35.

Otani, I. and Villanueva, D. (1989), "Theoretical aspects of growth in developing countries: external debt dynamics and the role of human capital", Staff Papers, Vol. 36 No. 2, pp. 307-342.

Pattillo, C., Poirson, H. and Ricci, L. (2004), "What are the channels through which external debt affects growth?”, IMF Working Paper, Vol. 2004, Issue 015, doi: 10.5089/9781451843293.001.

Pattillo, C., Poirson, H. and Ricci, L.A. (2011), "External debt and growth”, Review of Economics and Institutions, Vol. 2 No. 3, p. 30.

Pegkas, P. (2018), "Government debt and economic growth. A threshold analysis for Greece", Peace Economics, Peace Science and Public Policy, Vol. 25 No. 1.

Pesaran, M.H., Shin, Y. and Smith, R.J. (2001), "Bounds testing approaches to the analysis of level relationships", Journal of Applied Econometrics, Vol. 16 No. 3, pp. 289-326.

Reinhart, C.M. and Rogoff, K.S. (2010), "Growth in a time of debt", American Economic Review, Vol. 100 No. 2, pp. 573-578. 
Reinhart, C.M., Reinhart, V.R. and Rogoff, K.S. (2012), "Public debt overhangs: advanced-economy episodes since 1800", Journal of Economic Perspectives, Vol. 26 No. 3, pp. 69-86.

Shin, Y., Yu, B. and Greenwood-Nimmo, M. (2014), "Modelling asymmetric cointegration and dynamic multipliers in a nonlinear ARDL framework", in Festschrift in Honor of Peter Schmidt, Springer,

\section{External debt-growth \\ nexus} New York, NY, pp. 281-314.

Shkolnyk, I. and Koilo, V. (2018), "The relationship between external debt and economic growth: empirical evidence from Ukraine and other emerging economies", Investment Management and Financial Innovations, Vol. 15 No. 1, pp. 387-400.

Stylianou, T. (2014), "Debt and economic growth: is there any causal effect? An empirical analysis with structural breaks and Granger causality for Greece", Theoretical and Applied Economics, Vol. 21 No. 1, pp. 51-62.

Toktaş, Y., Altiner, A. and Bozkurt, E. (2019), "The relationship between Turkey's foreign debt and economic growth: an asymmetric causality analysis", Applied Economics, Vol. 51 No. 26, pp. 2807-2817.

Zivot, E. and Andrews, D.W.K. (2002), "Further evidence on the great crash, the oil-price shock, and the unit-root hypothesis", Journal of Business and Economic Statistics, Vol. 20 No. 1, pp. 25-44.

\section{Corresponding author}

Mesbah Fathy Sharaf can be contacted at: sharaf@ualberta.ca 
JBSED

2,1

\section{Appendix}

Dependant variable Forcing variables

Specification

bounds

Table A1.

$\Delta$ (lnGDP perworker) $\quad \ln K, \ln H$, lndebt

ARDL $(1,3,4,4)$

$F$-statistic

$\mathrm{I}(0)$

$\mathrm{I}(1)$

Cointegration

Note(s): The lower and upper bound critical values are obtained from Pesaran $e t$ al. (2001)

ARDL $(1,3,4,4)$

Panel (A)

Short run coefficients

Trend
$\Delta(\ln K)$
$\Delta(\ln K(-1))$
$\Delta(\ln K(-2))$
$\Delta(\ln H)$
$\Delta(\ln H(-1))$
$\Delta(\ln H(-2))$
$\Delta(\ln H(-3))$
$\Delta(\operatorname{lndebt})$
$\Delta(\operatorname{lndebt}(-1))$
$\Delta(\operatorname{lndebt}(-2))$
$\Delta(\operatorname{lndebt}(-3))$
$\left.\Delta(\operatorname{lndebt})^{+}\right)$
$\Delta\left(\operatorname{lndebt}{ }^{-}\right)$
$\Delta\left(\operatorname{lndebt}{ }^{-}(-1)\right)$
$\Delta\left(\operatorname{lndebt}{ }^{-}(-2)\right)$
ECT $_{t-1}$

$-0.52 * * *$

Panel B

Long run coefficients

\begin{tabular}{llllr}
\hline $\ln K$ & $0.15^{* * *}$ & 0.02 & $0.41^{* * *}$ & 0.07 \\
$\ln H$ & 0.09 & 0.009 & $0.38^{*}$ & 0.19 \\
$\ln \operatorname{lebt}^{\text {lndebt }}{ }^{+}$ & $-0.10^{* *}$ & 0.04 & -0.05 & 0.04 \\
lndebt $^{-}$ & & & $-0.38^{* *}$ & 0.14 \\
\hline
\end{tabular}

Diagnostic tests $\quad$ ARDL $(1,3,4,4) \quad$ NARDL $(1,3,3,1,2)$

A: Serial correlation
B: Heteroskedasticity
C: Functional form
D: Normality

Table A2.

Estimated short run and long run parameters of the $\operatorname{ARDL}(1,3,4,4)$ and NARDL $(3,3,1,3,3)$ models
0.10

$\begin{array}{ll}-0.05^{* * *} & 0.01 \\ -0.06^{* *} & 0.02 \\ -0.07 * * & 0.02 \\ -0.10^{* * *} & 0.03 \\ -0.16^{* * *} & 0.02\end{array}$

$$
\begin{gathered}
\chi^{2}(2)=2.24 \\
p \text { value }(0.13) \\
\chi^{2}(16)=14.16 \\
p \text { value }(0.58) \\
F(1,18)=0.20 \\
p \text { value }(0.65) \\
\text { Jarque-Bera }=2.81 \\
p \text { value }(0.24) \\
R^{2}=0.99 \\
\text { Adjusted } R^{2}=0.99
\end{gathered}
$$

NARDL $(3,3,1,3,3)$

S.E

0.01

0.02

0.02

0.03

0.03

$-0.11 * * *$

$-0.07$

0.04

0.013

0.016

0.016

-

Note(s): A: Lagrange multiplier test of residual serial correlation

$\mathrm{B}$ : based on the regression of squared residuals on squared fitted values

C: Ramsey's RESET test using the square of the fitted values

$\mathrm{D}$ : based on a test of skewness and kurtosis of residuals 
External

debt-growth

nexus

\begin{tabular}{|c|c|c|c|}
\hline Null hypothesis & Long-run & Short-run & \\
\hline Symmetric effect of external debt on GDP & $\begin{array}{l}\chi^{2}(1)=2.11 \\
p \text { value }(0.14)\end{array}$ & $\begin{array}{l}\chi^{2}(1)=7.81 \\
p \text { value }(0.00)\end{array}$ & $\begin{array}{l}\text { Table A3. } \\
\text { Asymmetric } \\
\text { effects test }\end{array}$ \\
\hline
\end{tabular}

\begin{tabular}{lcccc}
\hline Break test & $F$-statistic & Scaled $F$-statistic & Critical value & Estimated break date \\
\hline 0 vs $1^{*}$ & 25.75 & 103 & 16.19 & 1992 \\
1 vs 2* & 15.12 & 60.48 & 18.11 & 2003 \\
2 vs 3* & 15.39 & 61.59 & 18.93 & 2009 \\
3 vs 4 & 1.51 & 6.06 & 19.64 & \\
Note(s): * denotes significant at the 0 0 05 level. The critical values are Bai-Perron (Econometric Journal, 2003)
\end{tabular}

Note(s): * denotes significant at the 0.05 level. The critical values are Bai-Perron (Econometric Journal, 2003) critical values. A trimming of 0.15 is used

Table A4.

Results of the multiple break points tests (Bai-Perron tests of $m+1$ vs $m$ sequentially determined breaks)

\begin{tabular}{lrcrr}
\hline & \multicolumn{4}{c}{ Multiple breaks sub-periods } \\
& $1980-1992$ & $1993-2003$ & $2004-2009$ & $2010-2019$ \\
\hline Constant & $0.91(0.96)$ & $9.56^{* * * *}(2.55)$ & $8.57^{*}(3.0)$ & $5.41^{* * *}(0.10)$ \\
$\ln H$ & $0.61^{* * *}(0.08)$ & $0.38(0.30)$ & $-0.68^{* * * *}(0.05)$ & $0.04(0.06)$ \\
$\ln K$ & $0.019(0.08)$ & $0.26^{* * * *}(0.07)$ & $0.13^{*}(0.05)$ & $0.15^{* * * *}(0.03)$ \\
ln debt & $0.15^{* *}(0.06)$ & $-0.21^{* *}(0.08)$ & $0.06(0.13)$ & $0.05^{* * *}(0.02)$ \\
Observations & 13 & 11 & 6 & 10
\end{tabular}

Note(s): The dependent variable is $\ln$ GDP. Standard errors are presented in the parentheses. ***, **,* denote statistical significance at the $1 \%, 5 \%, 10 \%$ level, respectively

Table A5.

Estimation results of the multiple structural breaks analysis 
JBSED

2,1

18
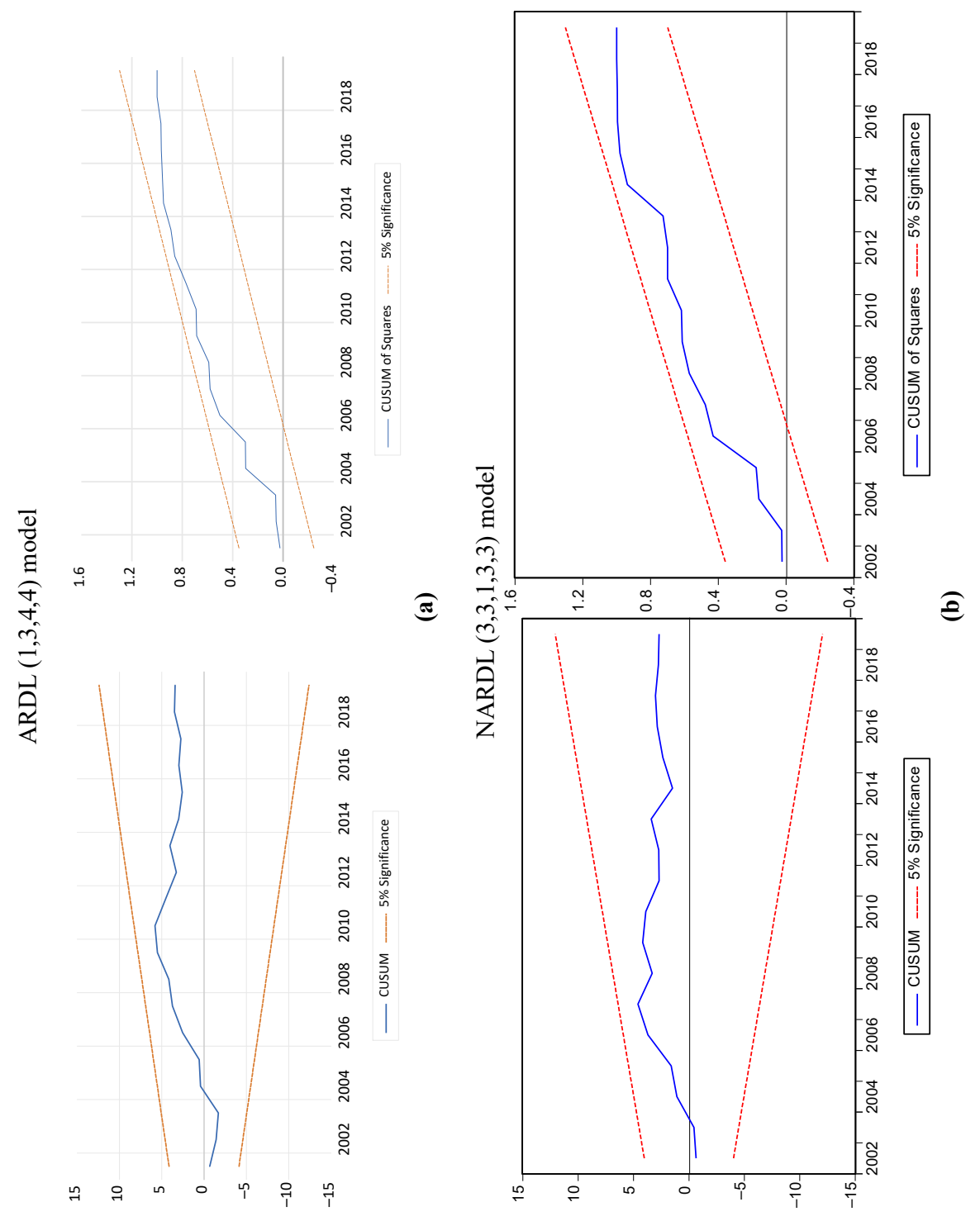

Figure A1.

ARDL (1,3,4,4) CUSUM and CUSUMSQ

stability plots 